\title{
Digital Monument Reconstruction in Architectural Studies: Synthesis of Research on the Previously Unknown Form of the Palace in Łobzów (Cracow) from the Period of the Rule of John III Sobieski
}

Piotr Pikulski*

vol. 9, 2020, 2, pp. 97-110

DOI: https://doi.org/10.33542/CAH2020-2-05

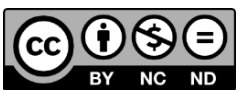

The former palace in Łobzów, which currently houses the Faculty of Architecture of the Cracow University of Technology, has an exceedingly rich architectural history. Since the Middle Ages, it has gone through a series of changes that have significantly altered its form each time. Thanks to modern digital reconstruction technology, it was possible to recreate all of its architectural phases in the form of 3D models on the basis of archaeological studies and the analysis of historical materials. The models were then used to reconstruct the most probable appearance of the building during the period when the Polish king John III Sobieski lived there. Determining the most probable state of the palace's preservation during King Sobieski's rule, which had not been investigated thus far, was possible only because of the combining of traditional research methods with modern technology.

Keywords: Łobzów Palace. Digital Reconstruction. Monument Protection. Architectural History. John III Sobieski.

\section{Introduction}

This text is a synthesis of studies on the architectural history of the former summer residence of Polish royalty in Łobzów near Cracow. From the beginning of its existence, this palace enjoyed great interest from Polish kings, who often preferred to stay here, among quiet natural surroundings, rather than in the Royal Castle on the Wawel Hill. The building currently houses the Faculty of Architecture of the Cracow University of Technology. The study, based on an analysis of archival materials and an analysis of historical sources (iconographic, topographic and written) utilized the digital reconstruction of buildings using 3D models. The models prepared during the study were collected and compared so as to perform a comparative analysis intended to determine the palace's appearance during the period when it was used as John III Sobieski's residence, who rebuilt it after the Swedish Deluge. Previously, the form it was given after this reconstruction and its degree were not known. The main course of the project is to create a complete digital documentation of all architectural phases of the palace in Łobzów, from the Middle Ages to the twenty-first century.

The former palace in Łobzów is located in Cracow in the present-day district of Krowodrza at 1 Podchorążych Street and currently houses the Faculty of Architecture of the Cracow University of Technology. Its contemporary form is the result of a remodelling project undertaken in the second half of the nineteenth century by Austrians, who adapted it into a Cadet School. The palace's architectural history is immensely rich. Its roots date to the Middle Ages and the rule of Casimir the Great, who sited his fortalicium (fortalice) here. ${ }^{1}$ Since that time, each subsequent period brought

Piotr Pikulski, Ph.D. Eng. Arch., Chair of History of Architecture and Monument Preservation, Faculty of Architecture, Cracow University of Technology, Cracow, Poland; piotr.pikulski@pk.edu.pl 
sweeping changes to the building's form, architectural style and, partially, even its function. Relatively much is known about each of them, primarily thanks to depictions of Cracow's panoramas and other iconographic or written sources.

\section{Historical outline: overview of studies on known states of the palace's preservation across the centuries}

The beginnings of the history of the Łobzów residence date back to 1357. It was then that King Casimir the Great took a particular liking to the village of Łobzów. He ordered his fortalicium to be built here. ${ }^{2}$ The erection of the structure was closely tied with the founding of Stary Łobzów and Nowy Łobzów in 1357 by Casimir the Great. Supposedly, the two villages were to form an economic infrastructure for a complex of buildings that guarded the Młynówka Królewska, a river that was a part of Cracow's water system during the period. The castle, described with the term fortalicium, together with similar fortresses throughout the region, belonged to the outer defences of the royal city. The form of the palace in this period is not known, but it is conjectured that its exterior and interior were not luxuriously furnished, so that the local population would not feel anxious about the king's presence. A hypothetical discussion of the fortalicium's appearance is possible on the basis of trace source materials and analogous gord ${ }^{3}$-like complexes. The primary element of the complex was a three-storey residential tower with a square-shaped plan. This was an element used in all knightly residences in the fourteenth century. ${ }^{4}$ Due to the shape of the terrain at the time (simple and flat), it appears logical that the floor plan of the entire layout could also have been based on a square. This would also be aligned in comparison with other castles founded by Casimir, such as Lanckorona or Skawina. ${ }^{5}$ The entire layout was most certainly surrounded by a wall and a moat, which could have been flooded thanks to the waters of the nearby Młynówka river. ${ }^{6}$

Together with Maksymilian Szpyt, the author attempted to finally determine the location of Casimir's fortalicium on the oldest known panorama of Cracow from $1536 .{ }^{7}$ These studies partially confirmed the supposition that the building survived to the fifteenth century in the form of a ruin, as its timber elements had fully deteriorated and only the masonry elements survived. It was possible that the original form of the residence erected by Casimir the Great was wooden and that only later remodelling projects gradually converted it into a masonry structure or, most probably, one with masonry ground floors and upper stories made of timber. ${ }^{8}$ There is a hypothesis that the oldest tower had two storeys, but it is impossible to prove this without locating the palace on the panorama of $1536 . .^{9}$

\footnotetext{
SZPYT - PIKULSKI, Obscure fate, 122.

GRABOWSKI, Kraków i jego okolice, 214.

medieval Slavic fortified wooden settlement

TOMKOWICZ, Teka Grona Konserwatorów, 116.

BOGDANOWSKI, Królewski ogród, 11-13.

HRYNIEWICZ, Royal Residence in Lobzow, 56-60.

PIKUSLKI - SZPYT, An attempt at establishing, 84.

RĄCZKA, Przemiany Krajobrazu, 25.

PIKUSLKI - SZPYT, An attempt at establishing, 86-87.
} 
In the fifteenth century, the palace often changed hands, yet none of its owners made any major modifications to its architectural form. ${ }^{10}$ The residence had slowly turned into a ruin, until it became the property of King Stephen Báthory. In 1585, he commissioned the complete remodelling of the building by the Italian architect Santi Gucci. ${ }^{11}$

The contract between Stephen Báthory and Santi Gucci, "a royal mason", 12 which stipulated the construction of a "new home"13 in Łobzów is a document that allows us to familiarize ourselves with the scope of the palace remodelling project. ${ }^{14}$ The contents of this document stipulate that, once completed, the building was to have seven rooms on the ground floor and seven rooms on the first floor. ${ }^{15}$ We know very little about the appearance and state of preservation of the fortalicium in Báthory's time. However, we do know that the ruler decided to site his own residence here, incorporating what had been left of Casimir's fortress into his own, thereby showing respect to the historical architectural tissue which had already been considered the legacy of an outstanding ruler. ${ }^{16}$ The king initially intended the new building to be merged with the "old tower", as stipulated in the contract. This was probably performed by using covered arcades. The term "old tower" was probably used to denote the oldest surviving part of the structure, the remains of the fortalicium's masonry tower. ${ }^{17}$

The death of Anna Jagiellon, who took particularly good care of the palace after the death of Stephen Báthory, put an end to this stage in the residence's architectural history. ${ }^{18}$

It was the remodelling performed during the rule of the Vasa dynasty at the end of the sixteenth and the start of the seventeenth century that gave the residence the form of the Baroque palace known from historic panoramas of Cracow. Sources state ${ }^{19}$ that the activity of Sigismund III and later his son Władysław IV in Łobzów was divided into a number of stages, each intended to further extend the building, as initiated by Stephen Báthory, while also implementing distinct elements of Vasa architecture. ${ }^{20}$

During the first stage of work on the Łobzów palace in the years 1594-1595, Sigismund III Vasa commissioned the extension of the eastern wing so as to add more rooms, ultimately "merging" the remains of the fortalicium's tower with the building's substance. The decision concerning this extension was dictated by the necessity to prepare the palace for the birth of Sigismind III's son, Władystaw IV, who was born in 1595 in the palace some months after construction work was completed. A double-bay layout was used in the new wing. From a courtyard-facing hall that

\footnotetext{
10 SZPYT - PIKULSKI, Obscure fate, 123.

11 FISHINGER, Santi Gucci, 142.

12 "murarzem królewskim"

13 "nowego domu"

14 FISHINGER, Santi Gucci, 142-143.

15 KIESZKOWSKI, Biuletyn Historji, 11.

16 SINKO, Santi Gucci, 24.

17 KIESZKOWSKI, Biuletyn Historji, 14.

18 lbidem, 15.

19 Ibidem, 12.

20 GRABOWSKI, Kraków i jego okolice, 215.
} 
originally belonged to Stephen Báthory's building one could now enter four rooms on the first floor and a spacious chamber and chapel on the second floor. ${ }^{21}$

One of the most significant changes in the history of the summer residence in Łobzów was made in the years 1602-1605, as a result of the adding of a new, single-bay wing from the south, "adding" it to Báthory's gallery, which now became an internal loggia open towards the courtyard. ${ }^{22}$ Thus, the frontal facade of the building ultimately lost all elements of Renaissance architecture, taking on the austere and simple appearance typical of Baroque palaces that we know from many of Cracow's panoramas. This facade, built as designed by Giovanni Trevano, is characterized by a main axis highlighted by a shallow avant-corps flanked by rusticated lesenes that are two stories high, as well as a rustic entrance portal that has survived to this day. ${ }^{23}$ Window openings were placed quite densely and lesenes were placed underneath first-floor windows. In addition, Trevano decided to use a protruding crowning cornice and to highlight facade corners using rustication. ${ }^{24}$

In the years 1655-1657, the palace was heavily damaged by the Swedish army. After this period there is a gap in known source materials as to its state of preservation. It is certain that during the reign of August II Łobzów remained a royal residence. ${ }^{25}$ It is known that August II visited it on 31 July 1697 prior to his coronation, as there were Swedes at Wawel Castle. However, August II's reign saw the gradual end of the palace's restored glory. ${ }^{26}$ The palace was gradually deteriorating for the remainder of the eighteenth century. Descriptions from 1736 and 1744 clearly illustrate the condition of the palace, which was unfit for the hosting of August III in Cracow. They mention leaks in the roof, dilapidated pavilions and overgrown gardens. Eighteenthcentury sources state that the eastern wing, which had remembered the period of Casimir the Great's fortalicium, was in the best condition, along with a stairwell and an adjoining chapel. ${ }^{27}$

The first iconographic source presenting the state of the palace after the Swedish Deluge is dated to the start of the nineteenth century. In 1809, Zygmunt Vogel and Jan Zachariasz Frey made a print depicting the Łobzów residence in a ruined state. It remained in this condition until 1802, when it became the property of Austrian authorities which commissioned an in-depth survey of the ruins and a design for its adaptive reuse as a Cadet School. The print by Vogel and Frey and the Austrian survey provided a basis for the building of a precise digital model of the residence's ruins.

21 STALA, The royal residence, 56.

22 KIESZKOWSKI, Biuletyn Historji, 17.

23 STALA, The royal residence, 58.

24 KIESZKOWSKI, Biuletyn Historji, 18.

25 BOGDANOWSKI, Królewski ogród, 28.

26 RĄCZKA, Przemiany Krajobrazu, 44.

27 RĄCZKA, Królewski Łobzów, 15. 


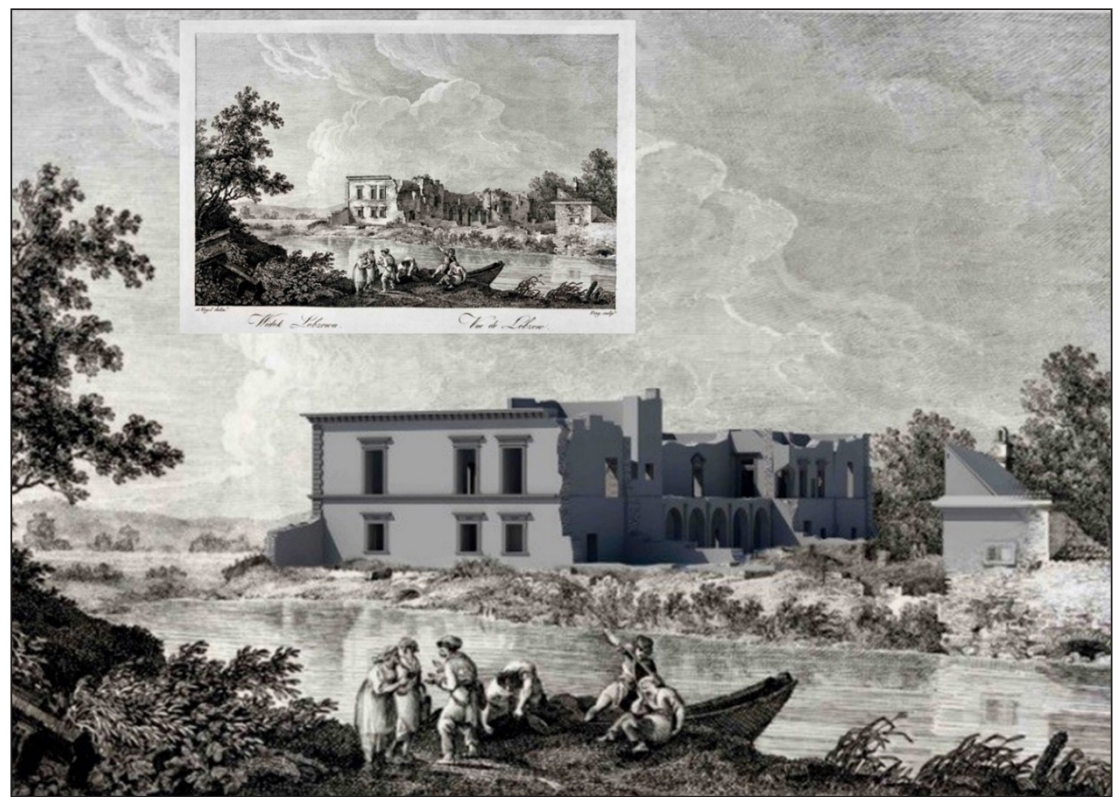

Figure 1: Insertion of the digital reconstruction of the Łobzów palace ruins as at the start of the nineteenth century onto the print by Jan Zachariasz Frey and Zygmunt Vogel; authors: Piotr Pikulski, Maksymilian Szpyt.

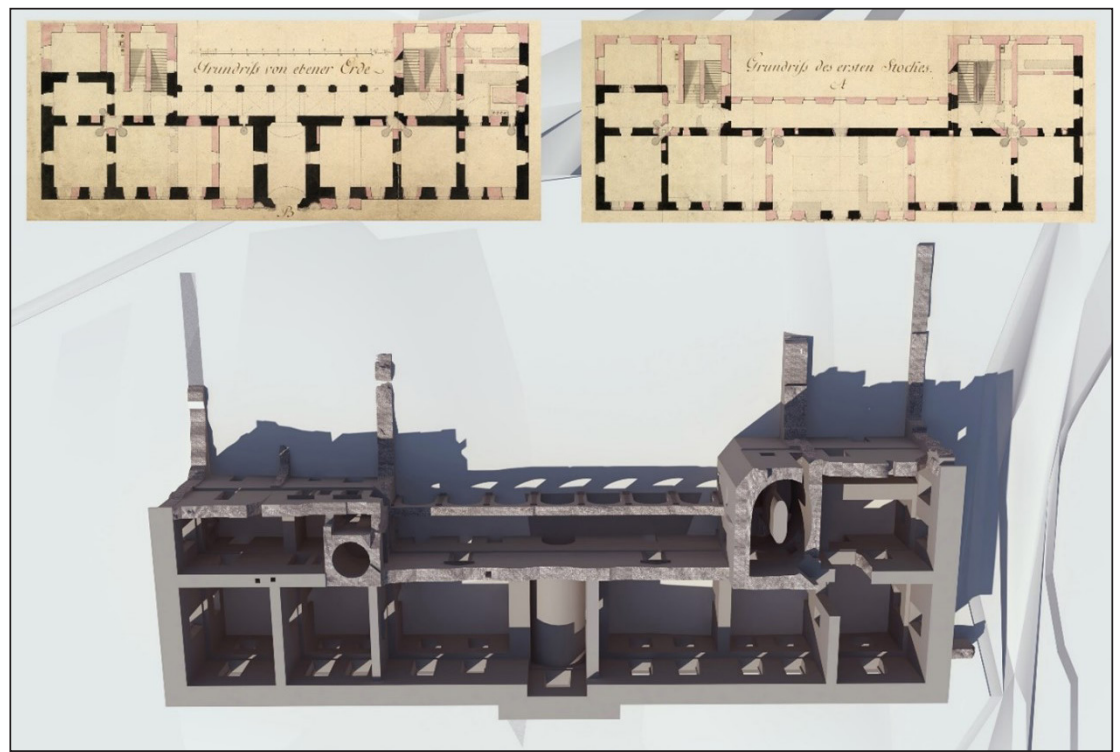

Figure 2: Digital model of the ruin as at the beginning of the nineteenth century, compared with the Austrian survey which was the primary information source for its preparation; authors: Piotr Pikulski, Maksymilian Szpyt. 
Discrepancies visible when comparing digital models of the Vasa-period form of the palace, the last state from before the Swedish Deluge that is known, and its nineteenth-century ruin, the first known state after its destruction by the Swedes, provide grounds for a theory that the palace could have been subjected to extensive remodelling between these two periods.

As reported by surviving historical sources, John III Sobieski lived in the Łobzów palace with his family and it was the place from which he departed to the Relief of Vienna. ${ }^{28}$ Archaeological research and archival studies performed by the author provided a basis for the hypothesis that the Łobzów residence was rebuilt by the hetman who would go on to be King of Poland in a form that differed from the one known before the damage wrought by the Swedes.

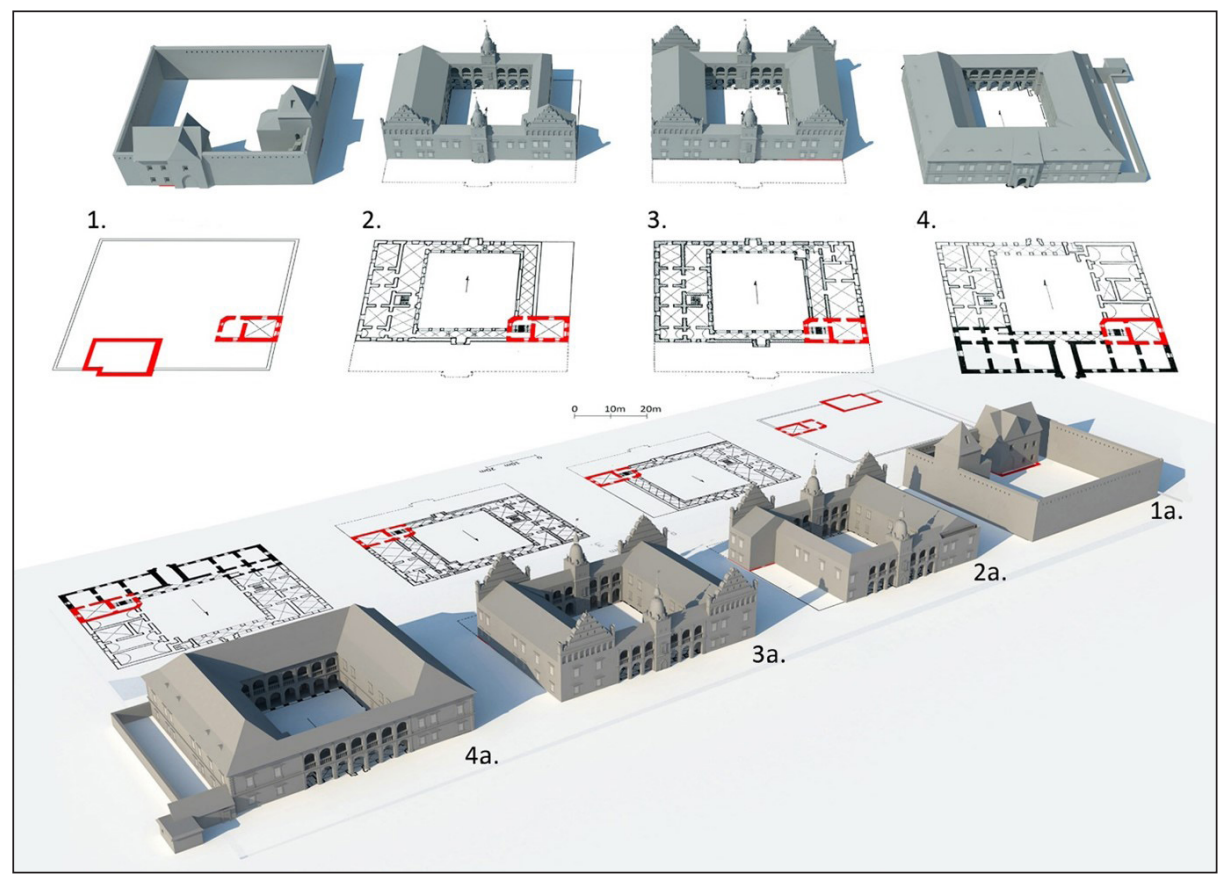

Figure 3: Comparison of the remodelling projects performed on the palace in Łobzów in the form of 3D models: 1, 1a-Casimir the Great's fortalicium; 2, 2a - the extension by Santi Gucci commissioned by Stephen Bathory; 3, 3a - extension by Sigismund III Vasa; 4, 4a - the remodelling by Giovanni Trevano commissioned by Wtadystaw IV Vasa, the supposed location of the remains of Gothic walls from the period of Casimir the Great has been marked in red; author: Piotr Pikulski. 


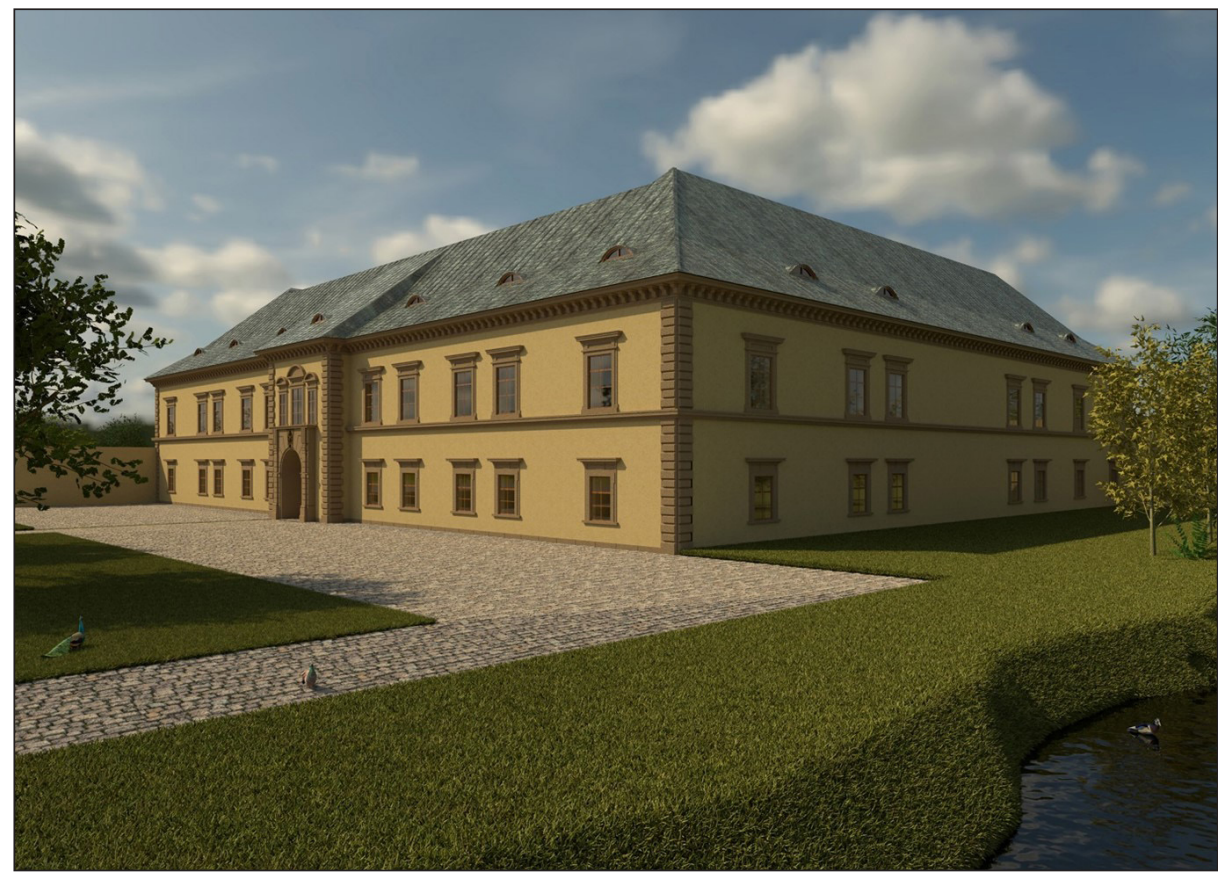

Figure 4: Reconstruction of the substance of the Łobzów palace after its remodelling by Wtadystaw IV Vasa, the final known form of the palace before the damage inflicted by the Swedish army; author: Piotr Pikulski.

\section{Damage inflicted on Cracow during the Swedish Deluge}

To determine the degree to which Sobieski had interfered with the substance of the Łobzów palace, it was necessary to identify the damage that the Swedes inflicted on it during their invasion of Poland in 1655. Historical sources speak little of the palace itself, yet we can find information fragments about what happened to it during the siege of Cracow. Most probably, and quite paradoxically, the fate of the Łobzów residence was sealed by the fact that on 28 September 1655 King Charles Gustav made it his quarters, where he had intended to prepare plans for the siege of Cracow. ${ }^{29}$ Out of tactical considerations, the Swedes refrained from damaging it and were content with looting and plundering the royal residence. It was only when the Poles began to forcibly resist the Swedish occupation that they started a massive campaign of destruction and terror in retaliation. Sources mention that any city, village or castle whose residents resisted the Swedes was sacked and razed or blown up afterwards.

In the case of Łobzów, there is mention of "great ruin being inflicted upon it"30 by Charles Gustav in retaliation for the armed resistance of the Poles. ${ }^{31}$ There are

29 LEPSZY, Polska w okresie, 440.

30 "doznaniu przez niego wielkiej ruiny"

31 GRABOWSKI, Kraków i jego okolice, 216. 
mentions of stripped flooring and marble column cladding, which was crushed and sold to craftsmen. The Swedes most probably treated Łobzów in the same as they had the castles in Tenczyn, Lanckorona, Pieskowa Skała, Lipowiec, Tyniec and Ojców and the palace in Niepołomice. Each was looted and then almost entirely or partially razed or blown up. ${ }^{32}$ Here it should be mentioned that the destruction was wrought in a period when the occupying forces had the upper hand over the Poles. In 1657, during their retreat from Poland, King Charles Gustav issued an official command to his forces to destroy everything in their path. It was never a decision made by individual commanders, but a blanket order to the entire army. ${ }^{33}$

There can be no doubt that it was during the Deluge that the palace had been stripped of its arcade courtyard, whose ruins are mentioned by, among others, A. Grabowski, who quoted Miechowita's accounts of his travels across Poland. ${ }^{34}$

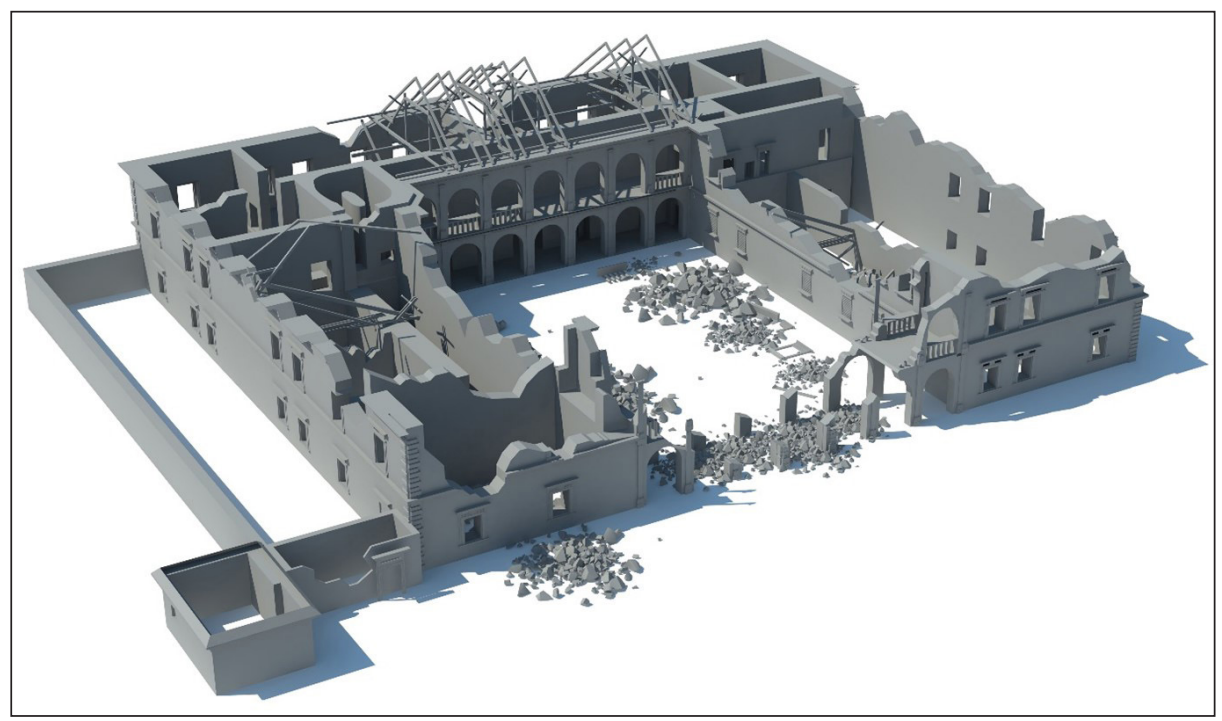

Figure 5: The probable condition of the Łobzów residence after the damage inflicted by the Swedish army during its invasion of Poland in the years 1655-1657. The figure presents the theoretical state of preservation of the palace after the demolition of the back arcades of the courtyard, which led to the collapse of some of the building's roofs and decks. The building was most certainly set alight, which caused the collapse of the remaining roofs and decks between storeys. The southern wing was most probably the least damaged due to its solid foundations, the fact that this section featured thick walls from the Middle Ages and the fact that this wing was the latest and therefore the most durable section of the palace; author: Piotr Pikulski.

Most probably, the palace was not blown up but rather set alight after being sacked and having some of the columns of its arcade courtyard hacked to pieces, causing it to partially collapse. One of the more significant consequences of this was the collapse of

32 SIKORA, Szwedzi i Siedmiogrodzianie, 119.

33 LEPSZY, Polska w okresie, 440.

34 GRABOWSKI, Kraków i jego okolice, 405. 
the palace's roof, which, after its timber structure had burnt down, could not support its remaining weight and fell upon the interior of the palace, completing the destruction caused by the demolition of some of the courtyard's marble columns. This must have resulted in the collapse of some of the decks above the ground floor of the south wing. The stairwells could also have been damaged during this event.

\section{Unknown activity by John III Sobieski at the Łobzów palace: digital reconstruction of the building's substance}

Previously, it was believed that the nineteenth-century ruin on Vogel and Frey's print and that described in the Austrian survey from 1820 was what remained of the damage done by the Swedish army. However, as argued by J. W. Rączka: "John III Sobieski uplifted Łobzów from ruin after its destruction by the Swedes, and had the garden arranged to French tastes". ${ }^{35}$ It is known that in 1665 the residence was still a ruin, but that Sobieski gradually rebuilt it. In the years 1683-1684, the palace was restored and was the site from where crown troops began their march to the Relief of Vienna in July 1683. It was also where Sobieski returned from his victory over the Turks, bringing to Łobzów the tent of Kara Mustafa himself. Most probably, the damage inflicted by the Swedes was so severe that Sobieski decided to renovate only a part of the building - the frontal section from the south, and fragments of the east and west wings, leaving the northern section and the arcade courtyard as they had been, in ruin.

Sources claim that when John III Sobieski became king, the costly construction of the palace in Wilanów and work on the Royal Castle in Warsaw forced the ruler to downscale his plans for the Łobzów residence and merely conserve it, and even to demolish some of its more deteriorated elements and use their materials on those projects. ${ }^{36}$ This is corroborated by a letter that Augustyn Locci, the architect and builder of Wilanów, sent to the king, in which he mentioned receiving "an entire column from Łobzów, and stated that no one knows what this stone is, as it is not local marble, but I know that it is Maro granito d'Egisto". ${ }^{37}$

What is certain is that Sobieski first saw the palace in ruin, with its eastern and western wings and the northern arcade wing severely damaged. Only the southern wing was suitable for extensive renovation, yet even here one could not avoid the complete reconstruction of the roof, destroyed during Swedish looting and razing. The remaining wings of the building required reconstruction instead of renovation, which Sobieski, then a Great Hetman of the Crown, could not afford. Because of this, he had to make a decision as to how to separate the renovated southern section from the preserved ruins of the eastern and western wings. Defining the places where the palace, as renovated by Sobieski, was "separated" from the ruins of its side wings is possible by analysing the digital reconstruction of the palace ruins as they were at the start of the nineteenth century. The efforts undertaken by Sobieski to restore the palace in Łobzów to its former glory and uplift it from ruin must surely be acknowledged as much more than mere renovation. The damage caused by the Swedes was extensive and although the building was not completely destroyed, many of its elements required reconstruction and partial remodelling.

\footnotetext{
35 RĄCZKA, Przemiany Krajobrazu, 36.

36 KIESZKOWSKI, Biuletyn Historji, 18-20.

37 Ibidem, 20.
} 
Thanks to having analysed the fate of the palace both prior to and after its reconstruction by Sobieski, it was possible to compare the resultant digital models of its individual architectural phases and superimpose them upon one another, creating the most probable image of the palace from its period as Sobieski's home. The uneven damage seen on the model of the nineteenth-century ruin confirms the hypothesis that Sobieski opted for only a partial reconstruction of the residence, leaving the side wings in disrepair so they could slowly deteriorate. Due to his only renovating the south wing, the building started to deteriorate once again after the king's death. This process progressed unevenly, hence the relatively good condition of the frontal section when compared to the rest of the building that can be seen on the nineteenth-century print.

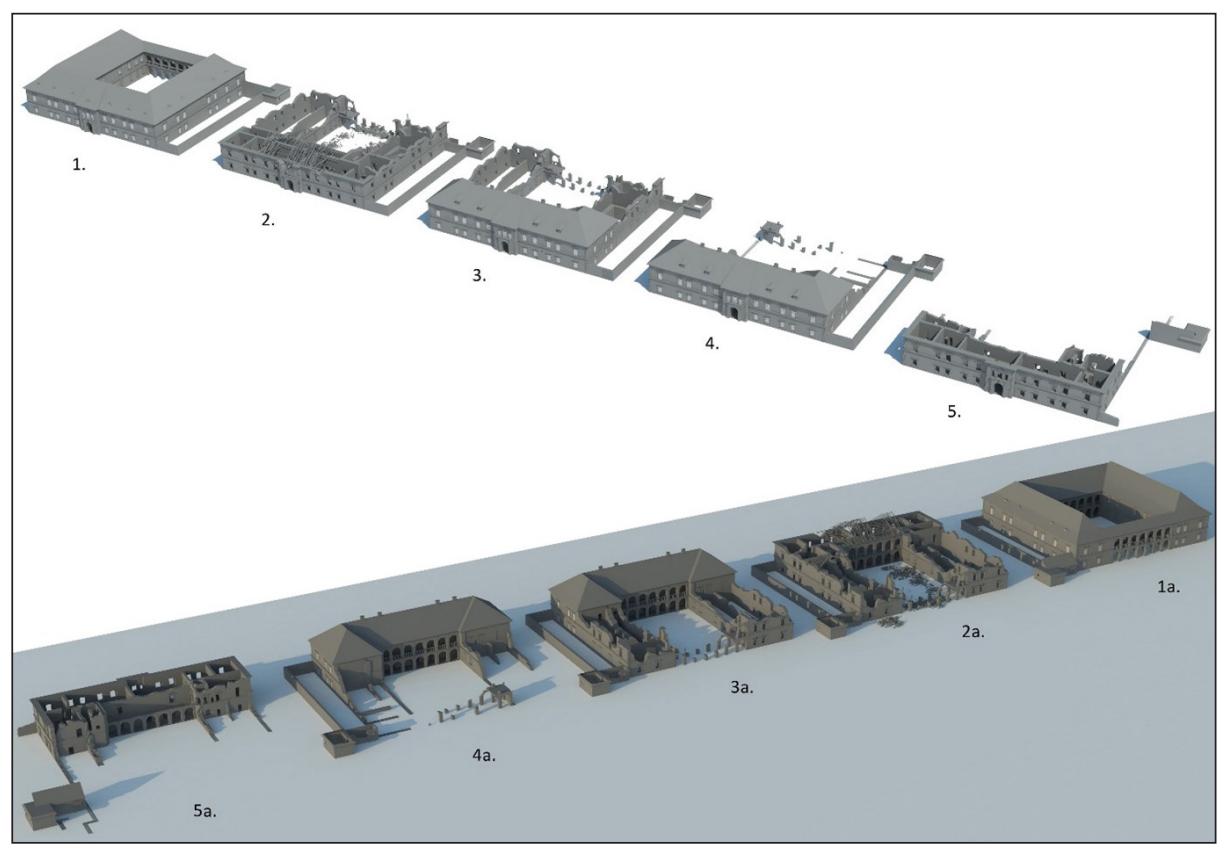

Figure 6: Comparison of digital models of the Reconstruction of the Łobzów palace, which led to the recreation of the state of the building's preservation during the period of John III Sobieski: $1,1 \mathrm{a}$ - state during the reign of Władystaw IV Vasa and the remodelling by Giovanni Trevano; $2,2 \mathrm{a}$ - state from the period of the building's destruction by the Swedish army during the Deluge; $3,3 a-$ the reconstruction by John III Sobieski after the damage inflicted by the Swedes; $4,4 \mathrm{a}$ - the reconstruction by John III Sobieski, state of preservation from the final years of the king's reign, when practically all remains of the side and northern wings were dismantled so as to reclaim construction materials for use on the Wilanów Palace; 5, 5a-nineteenth-century ruin. The progressive destruction of the north, east and west wings of the palace can be clearly seen on the image; author: Piotr Pikulski.

Another difficulty that Sobieski must have encountered during work on the restoring of the Łobzów residence for use was the matter of a new roof. As it used only small fragments of the side wings (a greater section of the east wing and a smaller section of the western wing), it was necessary to design a completely new roof geometry. Here, it 
can be said with a great deal of certainty that Sobieski could have given this task to his trusted Cracow-based court engineer Piotr Beber, who was most probably the author of the palace's reconstruction. Beber was famous for his talent at rebuilding damaged buildings, and specifically specialized in roof designs. Due to the assumption that it was Beber who designed the roof for the renovated palace, it can also be assumed that he used ceramic tiles as its surface layer, which he used the most of ten (he used it for the roofing in his design for the city hall building in Żółkiew) and which was much cheaper than copper sheets. ${ }^{38}$

It is certain that the frontal facade of the palace was not subjected to any major changes, as evidenced by the coat of arms of the House of Vasa on the entrance portal above the gate, still visible on nineteenth-century prints. In this case, the drawing by Józef Brodowski, depicting the facade from the front, is an invaluable source of knowledge about its appearance. It is on its basis that the authors were able to recreate the appearance of the building's facade in such detail.

The new side wings must surely have had traces left upon them after the wallingin of openings that had previously acted as doors connecting the entire eastern and western walls with the southern section. After Sobieski's remodelling, formerly interior walls became external walls, enclosing the new wings of the palace.

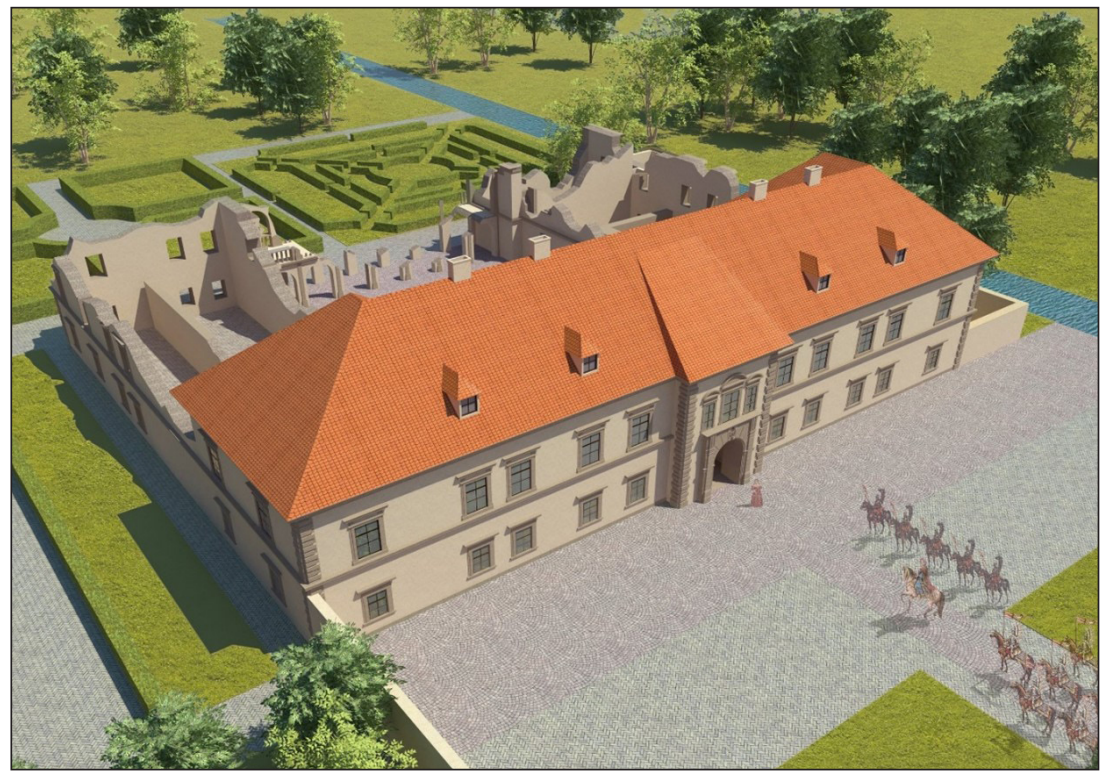

Figure 7: The Łobzów palace after its reconstruction by John III Sobieski, digital reconstruction of the probable state of the building's preservation ca. 1684, during the return of the king from the Battle of Vienna, view from the south, with the remains of the side wings and the arcade courtyard visible in the back; author: Piotr Pikulski.

38 PIKULSKI - STALA, Royal palace in Łobzow, 115. 


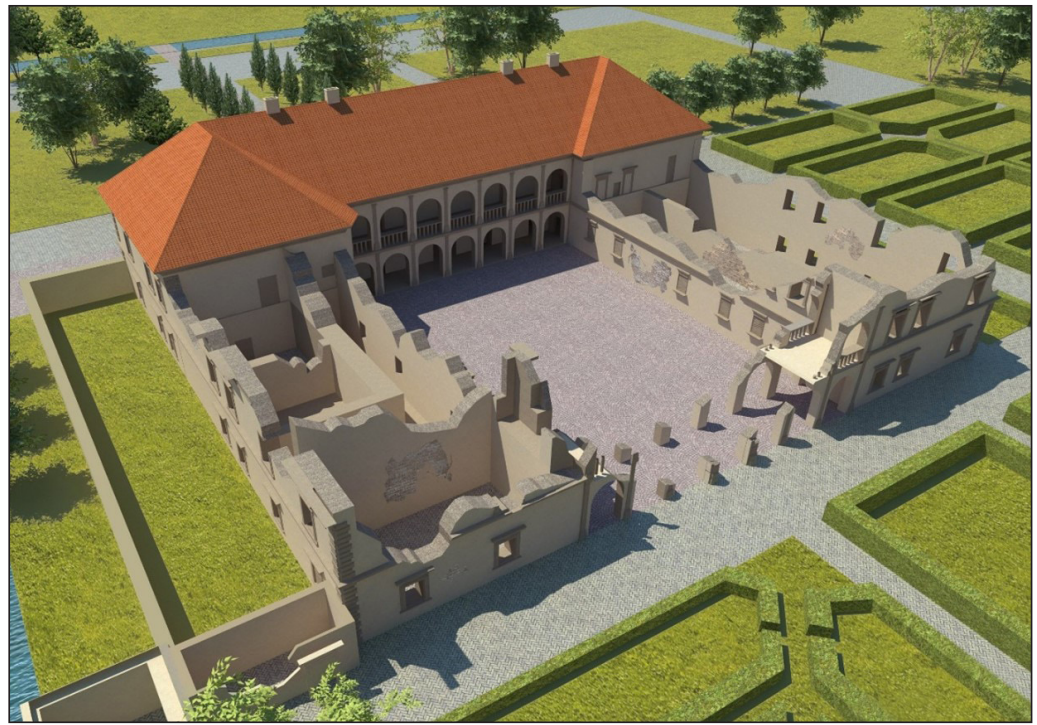

Figure 8: The Łobzów palace after its reconstruction by John III Sobieski, digital reconstruction of the probable state of the building's preservation ca. 1684, during the return of the king from the Battle of Vienna, view from the north, with the remains of the side wings and the arcade courtyard that had been destroyed by the Swedish army visible; author: Piotr Pikulski.

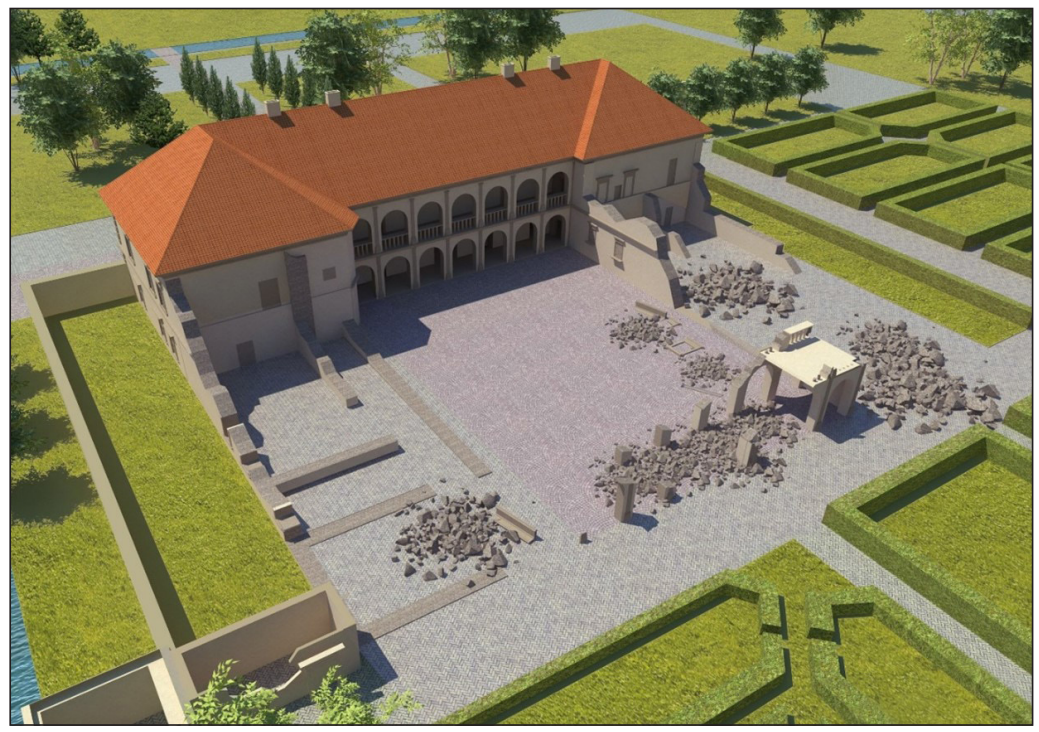

Figure 9: The Łobzów palace after its reconstruction by John III Sobieski, digital reconstruction of the probable state of the building's preservation from the final decade of the seventeenth century, after the gradual demolition of the remains of the eastern, western and the entirety of the northern wing so as to obtain materials that could be used in the construction of the Palace in Wilanów; author: Piotr Pikulski. 


\section{Conclusion}

It is certain that the reconstruction presented above is the most precise state of preservation of the palace in the state after Sobieski's interference that can be determined. Based on its analysis, it is possible to state that Sobieski must have rebuilt the front of the building and fragments of its eastern and western wings to a degree that made them habitable, leaving the northern section and the arcade courtyard in a damaged state. The uneven deterioration of the ruins can be seen as evidence of this. In the front section, the only significant deterioration is the lack of a roof, which is a normal phenomenon, as the timber roof frame decayed more quickly over time. The place of the clear "severing" of the eastern and western wings can be seen as evidence that the king deliberately gave up on the previously enclosed form of the building with a square courtyard at the centre, accidently contributing to the definition of the new form of the palace that has survived to this day.

The damage done by the Swedes was considerable, but there is no evidence to suggest they blew up the building (at least in its entirety). There are only mentions of them tearing away the flooring and generally devastating the interiors and walls, as well as of arson. Therefore, it can be assumed that Sobieski did not have to rebuild a complete ruin. However, his task involved something equally essential: he had to restore the palace to its former glory. To do so, the king had to make numerous key decisions during the works, concerning, among other things, how to rebuild the roof, how to pick major architectural details, which materials to use and how to decorate and finish the interiors.

It can be stated with certainty that the Łobzów palace as rebuilt by Jan Sobieski, the future king of Poland, considerably differed in form from that of the period of Trevano's remodelling, and the king himself considerably contributed to how the residence has been perceived in later years and the present.

Finding archival materials from the reign of Jan III Sobieski would make 3D reconstructions much more accurate, but archival inventories from 1665 and 1692, mentioned by Jan Rączka and Bogusław Krasnowolski, described the entire grange and gardens, not focusing sufficiently on the palace itself. Digital reconstruction of the gardens is the next planned stage of research. ${ }^{39}$

SketchUp Pro software was used to create the digital models shown in this paper. This software made it possible to import any archival architectural plans or iconographic materials into the 3D environment. It also allowed colour samples to be taken from them, in order to recreate the individual materials used during the construction of the palace. Parameters that could not be read from archival drawings (for example, floor heights) had to be found in archival inventories.

During the study, the method of the reconstruction using digital models of individual architectural phases of the summer residence in Łobzów and their subsequent comparison with the intent to discover a new, previously unstudied form of the building, can contribute to a significant enhancement of our knowledge concerning architectural and archaeological research of historical structures that have long since ceased to exist.

39 RĄCZKA - KRASNOWOLSKI, Królewska rezydencja, 86. 


\section{BIBLIOGRAPHY}

BOGDANOWSKI, Janusz. Królewski ogród na Łobzowie. Kraków: Towarzystwo Wydawnicze historia Iagellonica, 1997.

FISHINGER, Andrzej. Santi Gucci, architekt i rzeźbiarz królewski XVI wieku. Kraków: Ministerstwo Kultury i Sztuki, Zarząd Muzeów i Ochrony Zabytków, 1969.

GRABOWSKI, Ambroży. Kraków i jego okolice. Kraków: Józef Czech, 1850.

HRYNIEWICZ, Małgorzata, Royal Residence in Lobzow. Transformations from the 13 'th to the 20 'th century against the background of the research state analysis in chronological order. In: Technical Transactions Architecture and Urban Planning, 2018, vol. 10, pp. 55-70.

KIESZKOWSKI, Witold. Biuletyn Historji Sztuki i Kultury. Warszawa: Instytut Sztuki PAN, 1935.

LEPSZY, Kazimierz. Polska w okresie Drugiej Wojny Pótnocnej, Tom Drugi - Rozprawy. Warszawa: PWN, 1957.

PIKULSKI, Piotr - STALA, Klaudia. Royal palace in Łobzow in the times of Jan III Sobieski. Search for the author of the reconstruction project of the residence, based on the analysis of the architectonic achievements of Piotr Beber, Thieleman van Gameren and Augustyn Locci. In: Wiadomosci Konserwatorskie - Journal of Heritage Conservation, 2018, vol. 54, pp. 111-120. https://dx.doi.org/10.17425/WK54LOBZOW

PIKULSKI, Piotr - SZPYT, Maksymilian. An attempt at establishing the precise location of the Łobzow fortalice of Casimir the Great in the Panorama of Krakow from 1536/1537. In: Wiadomości Konserwatorskie - Journal of Heritage Conservation, 2019, vol. 59, pp. 83-89. https://dx.doi.org/10.17425/WK59LOBZOW

RA_CZKA, Jan - KRASNOWOLSKI, Bogusław. Królewska rezydencja w Łobzowie. In: Pałace i wille podmiejskie Krakowa. Kraków: Towarzystwo Miłośników Historii i Zabytków Krakowa, 2007.

RACZKA, Jan. Królewski Łobzów. Warszawa: Towarzystwo Wiedzy Powszechnej, 1980.

RACZKA, Jan. Przemiany Krajobrazu Podkrakowskiej Rezydencji Łobzów. Kraków: Politechnika Krakowska, 1996.

SIKORA, Leszek. Szwedzi i Siedmiogrodzianie w Krakowie. Kraków: Tow. Miłośników Historyi i Zabytków Krakowa, 1908.

SINKO, Krystyna. Santi Gucci Fiorentino i jego szkoła. Kraków: Wydawn. Związku Kół Historyków Sztuki Studentów Uniwersytetów Rzeczypospolitej Polskiej, 1933.

STALA, Klaudia. The royal residence of Zygmunt III Vasa in Łobzow. Attempt at reconstruction. In: Wiadomosci Konserwatorskie - Journal of Heritage Conservation, 2015, vol. 42 , pp. 54-60.

SZPYT, Maksymilian - PIKULSKI, Piotr. Obscure fate of the Palace in Łobzow during the reign of Jan III Sobieski. Attempt at computer reconstruction based on the analysis of the palace history since 1655 till the mid-19th century. In: Wiadomosci Konserwatorskie Journal of Heritage Conservation, 2016, vol. 47, pp. 119-124.

TOMKOWICZ, Stanisław. Powiat Krakowski - Łobzów. In: Teka Grona Konserwatorów Galicyi Zachodniej, 1906, Vol. II, pp. 118-121. 